All letters are subject to editing and may be shortened. Letters should be sent to the BJGP office by e-mail in the first instance, addressed to

journal@rcgp.org.uk (please include your postal address). Alternatively, they may be sent by post as an MS Word or plain text version on CD or DVD. We regret that we cannot notify authors regarding publication. Letters not published in the Journal may be posted online on our Discussion Forum. For instructions please visit: http://www.rcgp.org.uk/bjgp-discuss

\section{Salaried GPs}

I read Ding, et al's' paper regarding salaried GPs with interest. There are undoubtedly many salaried GPs happy in their posts, enjoying the lessened responsibility and increased flexibility. The noticeable area which the paper does not discuss, and indeed did not set out to discuss, is that of job satisfaction within salaried GPs. There is evidently a significant subset of salaried GPs who are far from satisfied, feel disempowered, and may feel like mere workhorses to their principals who earn more and may actually have more control over their own working lives.

The habit of replacing retiring partners with cheaper salaried GPs is in danger of creating a two-tiered workforce, with an understandably grumbling underclass.

\section{Martin Billington}

GP principal, The Crookes Practice, Sheffield. E-mail: mbillington@doctors.org.uk

\section{REFERENCE}

1. Ding A, Hann M and Sibbald B. Profile of English salaried GPs: labour mobility and practice performance. Br J Gen Pract 2008; 58(546): 20-25. DOI:10.3399/bjgp08X277357

\section{Authors' response}

We would like to thank Dr Billington for his interest in our article on salaried GPs. ${ }^{1}$ As he correctly notes, job satisfaction was not on our agenda - although we do briefly comment on the results of one such study on page 21 - but, in light of the concerns raised in his letter, it clearly deserves more attention.

We know of only two studies ${ }^{2,3}$ which have compared job satisfaction between salaried and principal GPs: neither found a significant difference in overall job satisfaction. Gosden, et al, ${ }^{2}$ which is the study alluded to above, did find that salaried GPs $(n=61)$ in PMS pilot practices were more satisfied with their remuneration and the recognition they received for good work, compared with 'standard contract' GPs, but were less satisfied with their colleagues and fellow workers and physical working conditions. This study was carried out on data collected in 1998-1999, and, as yet, there is no up-to-date evidence to support or oppose Dr Billington's statement.

Economic theory predicts that all types of GP should be equally happy if the market is sufficiently open to permit movement to their position of choice (for example, principal versus salaried). Only if the market constrains GPs to one type of position would we expect to find systematic differences in job satisfaction. It is unclear if such market constraints exist or are becoming apparent, for if they do, Dr Billington's concerns would be sustained.

\section{Alexander Ding}

Physician, Santa Clara Valley Medical Center, Cupertino, US.

E-mail: alexding@gmail.com

\section{Mark Hann}

Research Fellow (Statistician), University of Manchester, National Primary Care Research and Development Centre, Manchester.

\section{Bonnie Sibbald}

Professor, University of Manchester, National Primary Care Research and Development Centre, Manchester.

\section{REFERENCES}

1. Ding A, Hann M, Sibbald B. Profile of English salaried GPs: labour mobility and practice performance. $\mathrm{BrJ}$ Gen Pract 2008; 58(546): 20-26.

2. Gosden T, Williams J, Petchey R, et al. Salaried contracts in UK general practice: a study of job satisfaction and stress. J Health Serv Res Policy 2002; 7(1): 26-33.

3. Whalley D, Bojke C, Gravelle H, Sibbald B. GP job satisfaction in view of contract reform: a national survey. Br J Gen Pract 2006; 56(523): 87-92.

DOI: 10.3399/bjgp08X277366

\section{GPs' working lives}

Whalley, et al' report that GP job satisfaction and income have risen. Of their 2005 sample, $0.9 \%$ were salaried doctors, a group who make up $17 \%$ of the general practice workforce. ${ }^{2}$ I doubt whether the same level of satisfaction would be found among this group of GPs. Anecdotally, many feel underpaid and undervalued. Prospects for becoming a more autonomous partner are often poor or non-existent. There is a high staff turnover in these positions, which removes much of the continuity of care that for generations has meant so much to doctors and patients alike. This change in workforce composition may come to pose a threat to the nature of British general practice. Many unhappy salaried doctors may come to prefer working for Tesco or United Health rather than serve their more fortunate and more wealthy peers.

\section{Matthew Meacher Nisbet}

GP Registrar, Chawton Park Surgery, Chawton. E-mail:mnisbet@doctors.org.uk

\section{REFERENCES}

1. Whalley D, Gravelle H, Sibbald B. Effect of the new contract on GP's working lives and perceptions of quality of care: a longitudinal survey. Br J Gen Pract 2008; 58(546): 8-14.

2. The Information Centre. General and Personal Medical Services 2005. London: NHS Information Centre, 2007. http://www.ic.nhs.uk/statistics-and-data-collections/work force/nhs-staff-numbers/general-and-personal-medicalservices-2005-detailed-results (accessed 11 Feb 2008). DOI: 10.3399/bjgp08X277375

\section{Connecting for Health}

We are writing to you with severe concerns over the coverage that NHS Connecting for Health and the issue of confidentiality controls has received this week in the February edition of the BJGP. The Journal contains an editorial that argues against the current proposals for the summary care 
record with no attempt to balance the debate or explain the systems that are being proposed.

It is irresponsible to publish commentary on such an important issue for patient safety and confidentiality without the necessary balance expected from an academic journal. To promote a single agenda in such a blatantly campaigning way without an accurate representation of the facts in our view does the Journal, the College, and our patients a great disservice.

The editorial by Professor Ross Anderson seriously misrepresents the current consent model of the summary care model. Professor Anderson who is an advisor to a political campaign to get patients to opt out of the current arrangements also encourages GPs to support the campaign. Even the Editor himself seems to promote this view in his own comments, he challenges; 'Anyone going to join the opt-out campaign?'

The Big Opt Out campaign seems to be based on misinformation and has a much wider political context. To quote from the explanatory paragraph on the website:

'The NHS Confidentiality campaign was set up to protect patient confidentiality and to provide a focus for patient-led opposition to the government's NHS Care Records System. This system is designed to be a huge national database of patient medical records and personal information [sometimes referred to as the NHS 'spine'] with no opt-out mechanism for patients at all'.

We should be informing our patients that for the summary care record this statement is not true and as clinicians we have a professional duty to inform our patients in a responsible and balanced way, and point them to reliable sources of information.

The BJGP has given the impression of promoting a campaign to encourage patients to opt out of the summary care record in a way that risks undermining patient care on the basis of an inaccurate and biased position. There is no balancing of the Big Opt Out Campaign position with what is actually happening in the early adopter areas and what measure of control patients have should they wish to limit their participation. These measures are being independently evaluated and for an academic publication it is disappointing there is no mention of this.

In the same edition the article by Gordon Baird on the experience of an emergency care record in Scotland is equally biased away from central patient databases. ${ }^{2} \mathrm{He}$ even admits to encouraging his patients to opt out of the system by sending a letter to his patients that gave 'a rather unbalanced view.' This is particularly unfortunate as the Scottish emergency care record is widely felt to be a success. It is used by GP outof-hours services and by emergency departments and is popular with both doctors and patients.

Dr Clare Gerada offered the support of the College only 2 weeks ago during the Summary Care Record Advisory Group when we discussed the problem of myth and misinformation that is clearly being pushed out at the medical profession.

Although we understand that the BJGP has editorial freedom, it seems to be embarking on a campaign and if this was not the intention then the judgement of the Journal must be called into question. It is worthy of note that last year an article that was offered on changing the face of referrals and Choose and Book by Dr Mark Davies, Medical Director of Choose and Book, at the time was turned down by the Editor on the basis that he was biased.

Since there is a full month until the next edition of the BJGP much harm could be done to the GP perception of the College position until that time. We have received a number of enquiries already asking us if this is the new RCGP policy position.

We would be grateful for a statement clearly distancing the College from the position taken by the editorial. We would also like an opportunity in the Journal to give a more balanced view and address some of the myths that have now been promulgated.

\section{Michael Thick}

Chief Clinical Officer, NHS Connecting for Health. E-mail: Michael.thick@nhs.net

\section{Mark Davies}

National Clinical Director, NHS Connecting for Health.

\section{Simon Eccles}

National Clinical Director,

NHS Connecting for Health.

\section{Gillian Braunold}

Clinical Director Summary Care Record and Healthspace.

\section{Marlene Winfield}

National Patient Lead,

NHS Connecting for Health.

\section{Manpreet Pujara}

National Clinical Lead for General Practice, NHS Connecting for Health.

\section{Peter Short}

National Clinical Lead for General Practice, NHS Connecting for Health.

\section{REFERENCES}

1. Anderson R. Confidentiality and Connecting for Health Br J Gen Pract 2008; 58: 75-76.

2. Baird G. Confidentiality: what everyone should know, or, rather, shouldn't ... Br J Gen Pract 2008; 58: 131-133. DOI: 10.3399/bjgp08X277384

\section{On strengthening primary care}

De Maeseneer, et al's' editorial reflect our experiences delivering health care in the rural areas of Malawi's central region.

Our NGO's initial work was in AIDS orphan support and AIDS education; in every village we found a significant number of children needing medical attention for acute and chronic conditions. Investigation found they had no practical access to medical care, because of poverty and geographical location. Typically the tarmac road would be over $25 \mathrm{~km}$ away and the nearest health facility a further $40 \mathrm{~km}$. If the sick child made the journey, the choice would be between a government hospital where treatment, although free, is limited from chronic shortages of clinical staff and pharmaceuticals, or the mission sector where treatment is paid for, often beyond the means of the poor.

Our response was to set up a children's mobile clinic, taking primary health care to the villages. Utilising $4 \times 4$ vehicles stocked with a wide range of medicines, our team of clinical officers and nurses treat over 30000 sick children annually.

On our busiest day in 2007 , our two 